\title{
TABLICA PAMIĘCI SENATORÓW II RP
}

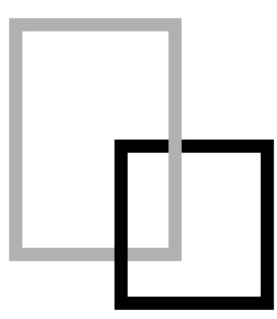

\author{
Memorial Plaque of Polish Senators
}

Jarosław Maciej Zawadzki*

SUMMARY: History of commemorate plaque 150 polish senators-victims of the Second World War. The commemorate plaque was unveiled in Senate in 1999. Some Senators don't have a graves. The commemorate plaques, it's the one place where we can find name and surname of Senators, which are carved into the stone. People who worked in the Chancellery of the Senate after 1989 tried to get some information about Polish Senators and their life during the wartime. We have interesting documents with biographical info. There are valuable things because the Archive of the Senate doesn't include materials of the polish Senate (1922-1939). Thanks to senators families we have valuable documents, photos etc. The "virtual memorial plaque" was launched on polish senate's webside in 2009. The "virtual memorial plaque" complements the "real" memorial plaque. The documents we have are very helpful for publications about history of Senate. The Chancellery of the Senate creates also an exhibitions about polish parliamentarianism.

KEYWORDS: senate, senator, parliament, memorial plaque, II World War

Niniejszy tekst przybliża historię powstania tablicy będącej upamiętnieniem senatorów - ofiar II wojny światowej, odsłoniętej w gmachu Senatu RP w 1999 r. Niespodziewanie jej realizacja, a głównie kwerenda dotycząca ustalenia losów senatorów, spowodowała powstanie unikalnej dokumentacji w postaci kolekcji teczek biograficznych przedwojennych senatorów. Materiałów tym cenniejszych, że nie zachowały się archiwa przedwojennego Senatu. Zebrane materiały zainspirowały do stworzenia w 2009 r. wirtualnej wersji tablicy na senackiej stronie internetowej. $\mathrm{W}$ ten sposób każda $\mathrm{z}$ postaci upamiętnionych na tablicy ma na internetowym odpowiedniku swój biogram oraz zdjęcia. Tablica wirtualna stała się uzupełnieniem realnej, marmurowej tablicy.

Latem 1989 r. na jednym z pierwszych posiedzeń odrodzonej i wyłonionej w całkowicie wolnych wyborach izby wyższej senator Roman Ciesielski zgłosił potrzebę upamiętnienia przedwojennych senatorów - ofiar II wojny światowej. Wniosek poparł marszałek Andrzej Stelmachowski i wicemarszałek Andrzej Wielowieyski. Zadanie przyjęła tworzona Kancelaria Senatu. Wkrótce okazało się, że nikt $\mathrm{z}$ historyków jeszcze nie badał tego tematu. Nie wiadomo 
było ilu senatorów wybrano $\mathrm{w}$ dwudziestoleciu międzywojennym i jak potoczyły się ich losy. ${ }^{1}$ W latach PRL historycy nie zajmowali się tzw. sanacyjnymi senatorami jako zbiorowością. Po apelach w mediach zaczęły zgłaszać się rodziny senatorów, wnuki, dzieci, a w niektórych przypadkach sędziwe wdowy. Zaczęto poszukiwać i gromadzić informacje. Postanowiono, że tablica będzie zawierać nazwiska wszystkich senatorów, którzy zostali zamordowani, zmarli lub zaginęli w latach wojny i wybrano jej lokalizację. W połowie lat 90 . prace nad listą nazwisk były już tak zaawansowane, że zlecono opracowanie projektu tablicy. Miała zawierać oprócz napisu głównego około 150 nazwisk wraz z rokiem i miejscem śmierci. Niespodziewanie w 1996r. realizację tablicy wstrzymano. Wydano jednak niskonakładową broszurę ukazującą dzieje senatorów oraz zestawienie biogramów senatorów zmarłych, zaginionych lub zamordowanych w czasie wojny. Dzięki odzewowi na to wydawnictwo udało się doprecyzować losy senatorów, a w niektórych przypadkach ustalić że zmarli przed lub po wojnie, a tym samym wykluczyć z zestawienia zaginionych w latach wojny. W 1998 r. powrócono do planów. Tablicę odkuto wiosną 1999 r., a odsłonięto w trakcie obchodów 10. rocznicy odrodzenia Senatu RP.

Przedwojenne sale obrad obu izb parlamentu mieściły się w obrębie jednej nieruchomości o współczesnym adresie ul. Wiejska 4/6/8. Budynki z salą obrad Sejmu i salą obrad Senatu zostały poważnie uszkodzone w czasie wojny. W $1946 \mathrm{r}$. przeprowadzono referendum ludowe (tzw. głosowanie $3 \mathrm{x}$ tak). Jedno z jego trzech pytań dotyczyło zniesienia instytucji Senatu. Wkrótce po ogłoszeniu sfałszowanych wyników referendum pozostałości sali obrad Senatu rozebrano. Bohdanowi Pniewskiemu powierzono zadanie zaprojektowania kompleksu budynków sejmowych dostawionych do odbudowywanej sali Sejmu. Kompleks oddano do użytku w $1952 \mathrm{r}$. i funkcjonuje do dziś. Obecnie w miejscu po przedwojennym budynku z salą posiedzeń Senatu (wewnątrz zespołu parlamentarnego) jest nieznaczne obniżenie terenu wykorzystywane jako niewielki parking. Główny budynek dla odrodzonego Senatu przejęto na przełomie 1989 i 1990 r. po biurach Rady Państwa oraz Bibliotece i Archiwum Komitetu Centralnego PZPR 2 . Gdy w latach 90. rozpoczynano prace nad tablicą zdecydowano, że będzie ona zamontowana wewnątrz nowej siedziby izby wyższej, oddalonej o około $300 \mathrm{~m}$ od miejsca gdzie stała przedwojenna. Było to symboliczne nawiązanie do tradycji przez odrodzony Senat. Miała też uhonorować tych spośród senatorów II RP, którzy stracili życie w latach okupacji. Tak więc $\mathrm{w}$ zakresie symboliki komponent niematerialny składał się z dwóch równoważnych elementów. Pierwszy to odwołanie się do pracującego przed wojną przy ul. Wiejskiej Senatu RP, po którym jako instytucji współtworzącej prawo, praktycznie nie pozostał żaden namacalny artefakt w przestrzeni (np. dawna sala obrad) czy nawet pamiątka (np. laska marszałkowska). Instytucji, której ostatnie posiedzenie miało miejsce 2 września 1939 r., a której odrodzenie miało miejsce równo 50 lat później w 1989 r. w wyniku przemian ustrojowych. Drugi

1 Na ten problem zwrócono uwagę w: J. Jachymek, Charakterystyka składu osobowego sejmu i senatu w II RP, w: Rola posta i senatora w II RP, pod red. Jana Jachymka, UMCS, Lublin 1989, s. 11. Jako pierwsi tą zbiorowością zajęli się autorzy słownika biograficznego Kto był kim w Drugiej Rzeczypospolitej, pod red. Jacka M. Majchrowskiego i przy współpracy Grzegorza Mazura i Kamila Stepana, BGW, Warszawa 1994, s. 492-562, 565.

2 W. Horst, Kancelarie i Archiwa Centralnego Komitetu Wykonawczego PPS, Komitetu Centralnego PPR i

Komitetu Centralnego PZPR, Naczelna Dyrekcja Archiwów Państwowych, Warszawa 2006, s. 210. 


\section{Tablica pamięci senatorów II RP

z równoważnych elementów to świadoma decyzja, że tablica ma nie tylko posiadać ogólny napis dotyczący godnego upamiętnienia senatorów II RP, ale że musi zawierać listę imion, nazwisk, dat i miejsc śmierci wszystkich senatorów - ofiar wojny. Komponent materialny, marmurowa tablica znajduje się na ścianie głównego holu, na parterze budynku. W ważnych momentach jak jubileusze związane z Senatem czy np. Święto Niepodległości, pod tablicą pojawia się duży bukiet biało-czerwonych kwiatów. Niekiedy gdy do Senatu przybywa z oficjalną wizytą prezydent lub premier - składają oni w tym miejscu stosowną wiązankę. Wielu z dawnych senatorów nie ma swoich grobów i jest to jedyne miejsce gdzie w kamieniu wyryto ich imię i nazwisko. Dlatego miejsce to pełni szczególną rolę dla rodzin senatorów, utrwala indywidualną pamięć o ojcu, dziadku czy pradziadku. Zdarza się że docierają tu nawet potomkowie senatorów mieszkający w odległych krańcach świata np. w Australii, Kanadzie czy Izraelu. Tablica pamiątkowa jest stałym elementem wycieczek oprowadzanych po wnętrzach Sejmu i Senatu. Corocznie jest tu ok. 40 tys. osób.

Prace nad ustaleniem listy senatorów, entuzjazm rodzin popierających ideę odsłonięcia tablicy i związany z tym napływ pamiątek, fotografii i relacji poniekąd wymusiły stworzenie w Kancelarii Senatu kolekcji indywidualnych teczek biograficznych. Początkowo był to zestaw teczek senatorów - ofiar wojny, ale z racji na napływ materiałów związanych z senatorami zmarłymi przed i po wojnie zbiór przekształcił się w kolekcję teczek dotyczącą wszystkich 452 osób pełniących w latach 1922-1939 mandat senatora. Każdy parlamentarzysta ma założoną odrębna teczkę. Wkłada się do niej materiały pozyskiwane od rodzin (oryginały lub reprodukcje), spisane relacje, wspomnienia, fotografie, pamiątki, odznaczenia, kopie artykułów biograficznych, wzmianek, ślady po działalności publicznej, nekrologi, fotografie grobów itp. Jest to cenny zbiór dla historyków, socjologów i badaczy-regionalistów. Pozwala też na przygotowywanie dużych wystaw związanych z Senatem II RP oraz publikacji. W 2009 r. ukaza1 się bogato ilustrowany album ukazujący senatorów, którzy zmarli lub zginęli w latach wojny, a w 2012 r. tom o senatorach zmarłych po wojnie ${ }^{3}$. Co kilka lat są organizowane konferencje, na których badacze prezentują nowe ustalenia dotyczące Senatu, senatorów czy prawodawstwa II $\mathrm{RP}^{4}$.

W 2009 r. powstała idea, aby informacje o tablicy oraz o wymienionych na niej senatorach umieścić na senackiej stronie internetowej www.senat.gov.pl. W ten sposób powstała wirtualna Tablica Pamięci, która przeniosła senacki pomnik w cyberprzestrzeń. Po wejściu w internecie na wspomnianą stronę widoczna jest fotografia tablicy. Po najechaniu na dane nazwisko można otworzyć biogram senatora wraz z bibliografią oraz zobaczyć fotografie z nim związane. W 2012r. stronę uzupełniono o biogramy senatorów zmarłych po wojnie, a obecnie prowadzone są prace, aby udostępnić w ten sposób informacje i materiały dotyczące senatorów zmarłych przed wojną.

3 D. Mycielska, J. M. Zawadzki, Senatorowie zamordowani, zaginieni, zmarli w latach II wojny światowej, Kancelaria Senatu, Warszawa 2009; Jarosław M. Zawadzki, Senatorowie. Losy wojenne i powojenne, Kancelaria Senatu, Warszawa 2012.

4 Ostatnia z nich Senat II Rzeczypospolitej (1922-1939) „rzecznik rozsądku, rozwagi i miary” odbyła się 11 grudnia 2017 r. w gmachu Senatu RP. 


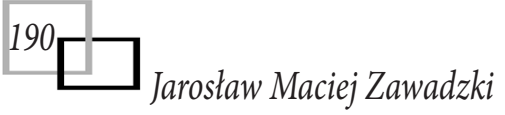

Zrodzona w 1989 r. idea, która urzeczywistniła się w 1999 r. odsłonięciem senackiej tablicy wpisała się w ciąg inicjatyw i wydarzeń w całej Polsce, które w zamierzeniu miały manifestować świadome nawiązywanie do II RP. Z jednej strony były to wydarzenia o wyjątkowej randze jak zmiana nazwy państwa, powrót korony do godła czy przekazanie w 1990 r. insygniów władzy II RP przez Ryszarda Kaczorowskiego, a z drugiej ogólnopolska akacja zmian nazw ulic czy placów oraz powstawanie pomników mających upamiętnić osoby lub wydarzenia, których pamięć przemilczano czy wręcz skazywano na niebyt w okresie PRL. Zdawano sobie sprawę z wielu problemów, z którymi zmagała się II RP, że nie było to państwo idealne, ale jednoznacznie traktowano je jako symbol czasów, w których Polska była pełnoprawnym podmiotem na arenie międzynarodowym, że miała swoje osiągnięcia. Jednym z nich było prawodawstwo, które współtworzyli przedwojenni senatorowie. Wydaje się, że powstałe w siedzibie Senatu RP upamiętnienie nie zamknęło sprawy senatorów II RP, że wręcz stało się impulsem do szukania sposobów szerszego informowania o ich życiu i dokonaniach nie tylko jako parlamentarzystów, ale jako obywateli pracujących na rzecz swoich lokalnych społeczności, grup etnicznych czy grup zawodowych. 